\title{
John Rawls Theory of Justice: Lessons for Eastern Libya Najeb Masoud
}

\author{
School of Accounting and Finance, Middle East University, PO box 383, Amman 11831, Jordan \\ *E-mail of the corresponding author: najeb2000@gmail.com
}

\begin{abstract}
Libya is a developing country and it has a unique culture, as any other country, with a significant position as the second largest oil producer in Africa. It has experienced dynamic changes over a short period of time. The aim of this study is to investigate the collapse of Gadhafi's regime in Libya has opened up space for new regional tensions over greater economic power and political representation, with hydrocarbon resources often used as a bargaining chip. There have been severe tensions surrounding the possible relocation of the headquarters of the National Oil Corporation (NOC) from Tripoli to Benghazi. The excessive oil profits are being taken away by foreign oil companies. Apart from that the foreign oil companies collude with corrupt government officials to disobey environmental laws. In the light of these problems, the thesis argued that Libya's oil resource is nothing but a curse and not a blessing. The situation has gone from bad to worse because too much emphasis has been placed on long term measures instead of short-term solutions. This is not more than scratching the surface while the substance of the problem is left untouched.
\end{abstract}

To achieve the aim and particular objectives of the study it was necessary to utilize more than one research method. Firstly, a descriptive method is used to provide an overview of accounting and its environment in a developing country, and the economic, social and political environment in Libya. Secondly, we choose John Rawls method of justice because it is designed to provide proposals which people cannot reasonable reject if they are committed to advance the welfare of everyone. In particular, it seeks to map the current idea which will be to develop short-term measures that no member of the current conflicts can reasonably object.

The content analysis showed that the Libyan government can approach the Eastern Libya oil crisis in a short-term course. The study argued that short-term justice will help to provide the immediate needs of tens of millions of neglected and impoverished citizens of Eastern Libya region in the meantime while the government continue to work on long-term solutions to her problems. The findings from the method of justice as propounded by John Rawls to produce specific short-term solutions that will solve the problem of economic injustice, political marginalization, social conflicts, and revenue distribution imbroglio.

Keyword: John Rawls, Theory, Justice, Eastern Libya

\section{Council for Innovative Research}

Peer Review Research Publishing System

Journal: International Journal Of Management \& Information Technology

Vol . 10, No 7

editorsijmit@gmail.com

www.ijmit.com 


\section{Introduction}

Libya is a developing Arab and Muslim country and the first significant oil producer and one of Europe's biggest North African oil suppliers and has been classified as "light" and "sweet oil". Historically, Libya had been occupied by several foreign powers, with the Phoenicians setting a colonisation trend that saw the Greeks, the Romans, the Ottomans and more recently the Italians followed by the British and France tutelage. Since independence, the Libyan political and economic system has seen several dramatic changes. The country's estimated population according to world Population Review 2014 is 6,244,174 people (KPMG, 2014). With regard to the Libyan aspect, like other Arab states, Libya is characterised by the extended family, clan, tribe and village, which play a significant role in the society's life and individuals' relationships with each other (Agnaia, 1997). Prior to the discovery of oil in 1959, agriculture was the primary sector. After the discovery of oil the Libyan economy grew rapidly as the country became richer, which attracted many international companies to operate in different sectors, specially the oil sector. The country's economy has become dependent on foreign oil companies predominantly from the UK and the US (Bait-El-Mal et al., 1973).

However, the oil sector was the main drive of the country's economy, with the contribution of oil to GDP over $50 \%$ in the 1970 s and early 1980s. As a result there was a great interest in developing the nonoil industrial sectors, which increased significantly, contributing over $70 \%$ of GDP in the late 1980s and early 1990s (Ahmed \& Gao, 2004). Nevertheless, the country still faced a great difficulty in being unable to produce enough capital goods and consumer goods to achieve "self sufficiency" and "self-reliance" (Agnaia, 1996). In fact, according to the IMF, the value of Libya's oil reserves per capita is the fifth highest in the world after Kuwait, Qatar, the United Arab Emirates and Saudi Arabia. Because of this oil wealth, many of Libya's macroeconomic indicators compare favorably with that of other African economies (KPMG, 2013).

However, the civil war caused oil production to fall to zero in August 2011, and, during 2011 as a whole, oil and gas production decreased by more than $70 \%$. This resulted in a massive contraction in real GDP, export earnings and fiscal revenues in 2011 (Figure, 1). The hydrocarbon sector made a quick recovery since the end of 2011 . In fact, crude oil and gas production rose to close to pre-crisis levels by end-2012. The sector is estimated to have expanded by about $195 \%$ in 2012 and to expand by another 14\% in 2013 and 4\% in 2014. In fact, by 2014, the International Monetary Fund (IMF) in estimates it's real GDP growth projection significantly lowers, from $-7.8 \%$ to $-19.8 \%$ (IMF, 2014). During the first half of 2014 , oil production averaged a meager $288,000 \mathrm{bpd}$, roughly $79 \%$ lower than the corresponding figure of $1.36 \mathrm{million}$ bpd produced on average during $2013 \mathrm{H} 1$. Therefore, the oil boom era assisted the country to successfully execute capital project. But the military incursion into politics coupled with huge political corruption changed political climate and the economic stability of the country. Furthermore, the lack of a negotiated and agreed moral principles and paradigm of social justice has affected the entire social structure of the country.
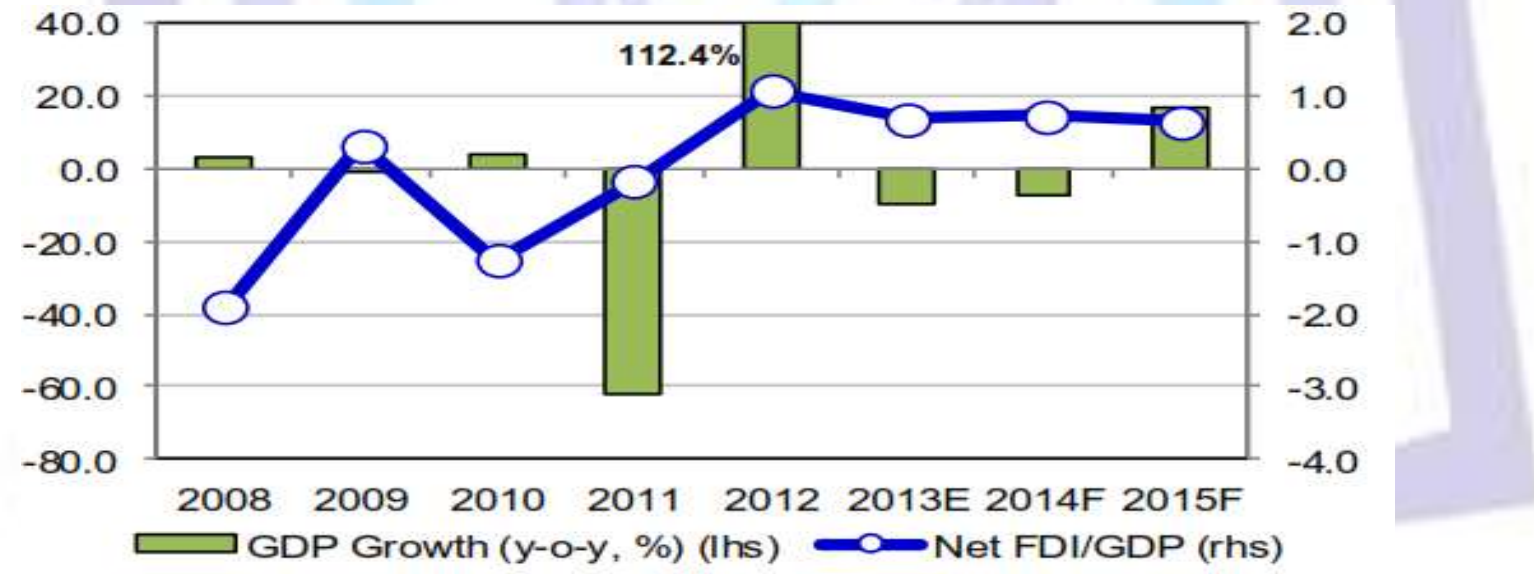

Figure 1. Real GDP Growth \& Net FDI/GDP (2008-2015)

Source: (NKC, 2014)

Sadly, the successive Libyan government have tried to solve these problems by setting up ad-hoc committees, organising constitutional conferences, creation of more states and mediation organisations to provide long-term solutions to these problems. These attempts have failed because government have continued to fashion out long-term solutions to the problems but to no avail. Apart from applying wrong approach to the problem, the government's lack the political will to implement their policies. The absence of elaborate and articulate social contract principles and the dearth of a coherent political philosophy based on some form of public principles of justice that has the capacity to take care of the aggregate interests of the Eastern Libya people in particular and Libyan's in general gives us a serious concern to ponder on the way forward.

In order to understand the need to pursue short-term rather than (or rather in addition to) long-term solutions to the Eastern Libya crisis, it is necessary to have a rich understanding of the history of the conflict; and all the things that have been tried and failed, the large number of parties involved and the diversity of their interests. Only against this backdrop can we see why the search for long-term solutions is unlikely to be fruitful, and only with such knowledge can we see why 


\section{ISSN 2278-5612}

there is a need for short-term solutions if people's lives are to be improved while the difficult fight for long-term justice continues.

\section{Research Question}

The following fundamental questions are raised by this study:

Q1, to what extent can we say that the colonial legacy and its attendant problems are responsible for the oil crisis that has plagued Libyan for three decades or more?

Q2, is the root-cause of economic injustice, social conflicts in Eastern Libya that of revenue mismanagement, unfair oilrelated legislation, environmental degradation or both?

Q3, Can we use John Rawls's method of justice to provide a set of short-term solutions to the socio-political and an economic problem that has plagued the Libya's Eastern Libya region in terms of oil crisis?

\section{Literature Review}

The history of oil discovery in Libya and its exploration over the past three decades has immensely increased the wealth of the country, but not without burdens and frustrations. It is shocking how often countries with oil and other natural resource wealth have failed to grow or develop fast than countries without oil and other natural resources. In the following years, the deterioration in the political relationship between the Libyan government and the West, especially the US, culminated in a ban on the import of Libyan oil and the export to Libya of U.S. oil industry technology in 1982 and the UN economic sanctions in 1992. This situation caused political and economic isolation of Libya for most of the 1990s. Since the start of the 2000s relations with the West have been gradually normalizing, ending the UN embargo in 2003, and the US embargo in 2004 (Masoud, 2013).

According to Act 5 in 1997, the Libyan Foreign Investment Board (LFIB) was established to attract foreign investment into Libya within a socialist framework of economic and social development. This Act and the subsequent amendments made to it in 2003 were aimed at promoting foreign investment through a partnership (joint venture) between Libyan and foreign capital in different sectors such as industry, health, agriculture, and tourism. With these developments and changes such as the increase in foreign direct investment, the emergence of the private sector and the privatization of the public sector, there has been a need for change in the accounting systems in general and the management accounting systems in particular to provide managers with relevant information to make their decisions (Masoud, 2014a).

Early in 2011, the Libyan crisis escalated, proposing another test for NATO that has undergone further transformation since the 2010 Lisbon Summit (Barnes, 2011). The US has always played a dominant role in carrying out international interventions in regional conflicts, but in the case of Libya, the US apparently hesitated to unfold military operations against Libyan military targets. It seems to be the first time that the US followed rather than led its European allies to a campaign. Although the US eventually decided to participate, it announced the decision to transfer the Libyan mission to NATO immediately after the campaign. To understand why the US preferred 'leading from behind' in Libya, James Mann analyses the events, ideas, personalities and conflicts that have defined Obama's foreign policy (Barnes \& Levinson, 2011). The debate over US commitment to NATO at this time is very serious, as the inherent problems of NATO were repeated in the post-Cold War period, firstly in Kosovo, then in Afghanistan, now peaking at Libya (Figure, 2).

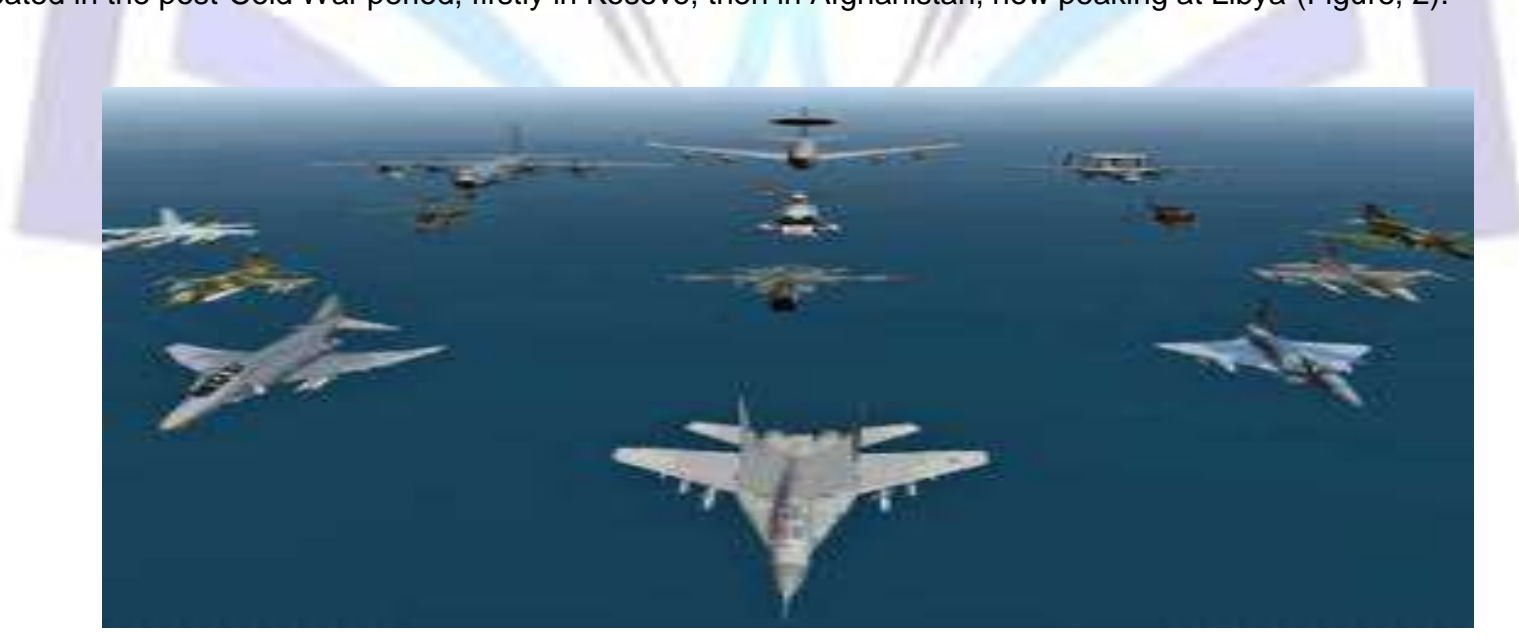

Figure 2. NATO Takes Command of Libya Operation as Allies Step Up Attacks

On the other hand growth in oil exporters is expected to decline in the short term due to fall of their oil supply and expected moderation of oil price. IMF (2013) reports that "A sustained decline in oil prices would leave many oil exporters in the (MENA) region with fiscal deficits". The oil price needed for budgetary break-even is now higher than the expected price for oil in 2014. Over the past several years, increased spending has raised fiscal break-even oil prices faster than actual oil prices have risen. As a result, a number of economies (including) Algeria, Bahrain, Iran, Iraq, Libya, Yemen, have fiscal break-even prices above the projected oil price for 2014. The case study on Libya is especially important in exploring the Obama administration's understanding of the purpose of NATO in the context of current economic 
pressures, domestic US debates about post-War on Terror interventions, and of increasing American preoccupation with Pacific rather than European security.

Apart from political corruption perpetuated by the Libyan leaders and the political class, the activities of the Libyan courts have come under serious scrutiny in relation to their roles in oil-related litigations. The time constraints are one of the ways the Libyan courts have used to frustrate litigants in oil-related matters and claimants of compensation payments. This legal barrier goes to suggest that Libyan courts are biased in favour of oil companies. The judges act as protector of the government oil interests and not an impartial arbiter. In most common law countries, lawsuits must be instituted within the statute of limitation of time. What this mean is that the plaintiff must bring law action within certain time frame and establish the causation between the harm and the defendant's conduct.

The Limitation Law process has been applied to frustrate peasant farmers and illiterate fishermen who do not have the means of gathering relevant information or evidence to their cases unlike the powerful oil companies who have the sophisticated technology and the financial strength to gather relevant information for any kind of litigation (Masoud, 2014b). The peasant farmers lack the financial power to fund legal action and the land where they make a living is being taken from them or destroyed by spills and pollution. So Limitation Law statute is one of the most fundamental factors hindering plaintiff access to justice. This problem has heightened confrontation between the oil bearing communities and the oil companies.

The challenges and weakness in solving these problems have much to do with the insincerity and lack of focus by the Libyan government. The insincerity of the government is a big problem and it has made some people resort to sabotage and other acts that are detrimental to public order. Resorting to violence is one option the Eastern Libya people have used to express their disappointment with the Libyan government. Although this is not the best option, the Eastern Libya people believe that this is the only way they can make foreign oil companies pay compensation for environmental destruction of their region so that it will be a big lesson to others. One of the cardinal issues this research set out to achieve is to provide short-term justice to the Eastern Libya oil crisis. This means that this study shall apply a method of justice that has the capacity to produce principles of justice that reasonable people who are determined to advance their collective interest cannot reasonably reject. This method of justice is plausible and defensible. This in fact shows how bad and complex Libyan problem has become. It is therefore important to mention that the country's problems are not unresolvable. The fundamental issue that we think is the greatest challenge is what practical approach and rational solution can be used to resolve them. If certain solutions have been unsuccessful, the question is why have those solutions failed. It is too late to blame anybody for these problems because recrimination will not solve the problems and we need to take action now.

The question that is begging for answer is for how long can we continue to blame our problems on the colonial administration? Indeed, the country's woes may not be solved if we continue to argue and debate on who is to blame. This will not in any way solve the problem. And for Libyan situation to remain together and one indivisible entity the problem of resource distribution, power sharing with associated imbalances, injustices, biases and other social problems should be amicably addressed. The solution to these problems will not happen overnight. And it is not going to happen with the caliber of greedy and corrupt politicians in government at present. However, it does not preclude that these problems cannot possibly be solved. The truth is we need the right mind-set and the right approach to solve our problems. Libya need a principle of justice that will have the ability to cash out and address such problems like economic injustice, political ostracism, insecurity problems and poverty. This is why in this study Rawlsian method of justice is applied to produce principles of justice that reasonable people who wish to advance their own good would not reasonable reject even if all our problems were not solved in one go. Those principle will be able to provide us with specific short-term solutions to our problems and equally give the Libyan government the opportunity to continue working on how to the rest our problems in the long-term course.

\section{Research Methodology}

The goal of the study is to find out key factors that led to a particular policy outcome. Having identified the research topic, specified its scope and developed theoretical frameworks, this section focuses on how to conduct the research study. First of all, it is necessary to clarify key propositions, the measurement of which determines the research approach. Then the research approach will be introduced in detail, focusing on 'why' and 'how' this approach is adopted. Finally, the expository analysis and presentation of the socioeconomic and political conditions in the Libyan's Eastern Libya region and the effects of the lack of proper, well-defined distributive process; lack of resource allocation formula governed by a public conception of justice or one based on social justice ideals, and lack of peaceful cooperation between the Eastern Libya people, the foreign oil companies and the Libyan government. The method clearly entails the presentation of salient issues about Eastern Libya region in concise and unbiased terms. Such issues like the historical antecedents of the region, political marginalisation and economic disempowerment, moral decadence and social injustice among other things. This is why we have to present a detailed analysis of political and economic problems confronting the country presently and why attempts to solve these problems have failed.

\section{Research Approach}

As it should in any sound research design, which it is based on a qualitative approach which is often used for policy and programme evaluation research because it can answer certain important questions more efficiently and effectively than quantitative approaches. The Rawlsian method will be adopt in this study. This method will help us develop proposals for instating short-term justice to address issues of economic injustice, political marginalisation, and social conflicts that are prevalent in the Eastern Libya discourse. Nothing about what I may be going to propose forecloses the continuing search for long-term solutions to Libyan's problems. I merely argue that we should not search only for long-term solutions. If we 
are going to improve the Libyan situation, and create an atmosphere where long-term solutions might actually be able to be agreed and imposed, we need to focus on short-term justice as well. Specifically, the research adopts the case study methodology, identifies four essential characteristics of a case study: particularistic, descriptive, heuristic, and inductive. As a result, by doing case studies, the researcher may gain a sharpened understanding of why the instance happened as it did, and what might become important to look at more extensively in future research. Our choice of John Rawls thought experiment as our methodology for the identification of principles of justice that will resolve both the economic and sociopolitical problems of Libya is the fact that it has the capacity to resolve principles and paradigms of social justice in a fair and just manner.

\section{Theory}

In the case of Libya, the control and management of natural resources and the sharing of its benefits has often been the chief motivator of ethnic or identity based conflicts. These problems are visible because Libya is a social country and not a decentralised system. Under these circumstances, we can say that the problems the country is experiencing now are due to the framework for the governing and management of natural resources and the wealth it generates. The country, in fact, has weak institutions and experiences the potentially destructive force of corruption and various actors' desperation to capture the wealth generated from these natural resources.

The two theories of natural resources is significant to this kind of research and also to show which one best suits the special circumstances of Libyan and which one Libyan is practicing now. In defining the two theories therefore, it will help us to advocate for equal distribution of resources and also consider how the principle of equal distribution can be justly implemented. But before we begin to define the two theories of natural resources, it is imperative to start with the terms "natural" and "resources".

\subsection{Natural Resource Theory}

The first theory states that natural resources belong to whoever happens to own them i.e. the land which is the founder. This theory means that the owner of the land where it is discovered is the owner and owns both the minerals and oil found there from. This theory is compelling in the sense that the landowner has absolute control of the minerals, fossil fuel, and gas found in his land. The owner decides who shares and who should benefit from it. The problem of sharing benefits does not arise. The management of the revenue remains the responsibility of the owner of the land or communities that jointly owes the land. In other words the management and control propensity of resource wealth resides with the person who owns the land and not with the State unless otherwise stated.

\subsection{Resource Theory}

The second theory provides that the natural resources belong to everyone and for the benefit of all. This theory gives the governing and ownership of natural resources to be managed by the State for the benefit and welfare of everyone. The argument in support of the second theory is that it allows everyone and not just people who happen to own a particular land that resources are on to share in the wealth those resources created. This theory has always been an emotional issue that requires balancing between the government and the oil-producing states. This is the theory Libyan and some other African countries are practicing currently. Sadly, this theory has failed to benefit everyone in Libya. The reason behind government control of the natural resources is to make sure that all population benefits but in Libyan nobody has benefited and not even the Eastern Libya people who "lays the golden eggs". So the fundamental question is if nobody has benefited except corrupt politicians and government officials who get pay-offs from the multinational oil companies, how can we reconcile or accept that the oil belongs to everyone? The claim that everybody owns the oil sounds too good to be true in Libya. The situation now is whereas one section could have benefited if they have control of the resources, it is rather a situation where the population do not benefits. And as result, the country is poor and backward even with her stupendous oil wealth. It is the corrupt politicians and those that have strong connections with oil companies that benefit. Since the population do not benefit, the next question is who benefits and how is the revenue accruing from oil resources distributed and allocated?

It is sad to note that the Libyan government does not consider ecological implications of oil spills but economic benefits derived from oil production. This is as a result of institutional failure (regulatory agencies) and the problem of anachronistic laws that needs urgent reform. Our environmental laws need urgent overhaul because it awards little or no penalties to defaulter and those perpetrators are let off lightly. However, the penalties prescribed by these laws lacks political will to implement and enforce them. Oil-producing companies deemed it less expensive to pay minimal fines than to re-inject gas. And as oil production generate substantial profits inflow into the pockets of oil companies, yet they have refused to pay fine for negligence cases against them. The average limit of gas flaring in the world is 4 per cent but Libya flares well above this limit (See Figure $3 \& 4$ ). 


\section{ISSN 2278-5612}

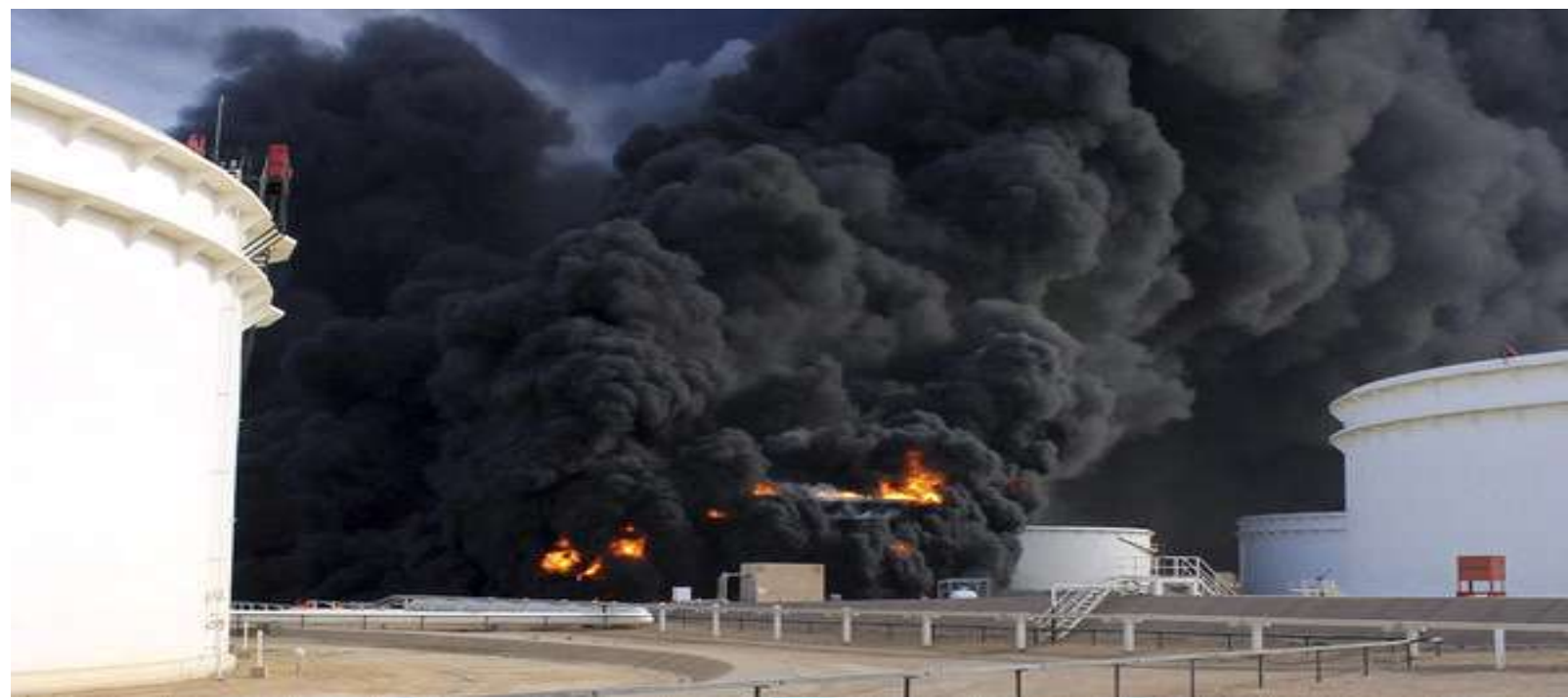

Figure 3. Seven of the 19 Oil Tanks at Al-Sidra were Ablaze

This photo shows the environmental and economic consequences as a result of this violence and destruction in the oil crescent area.

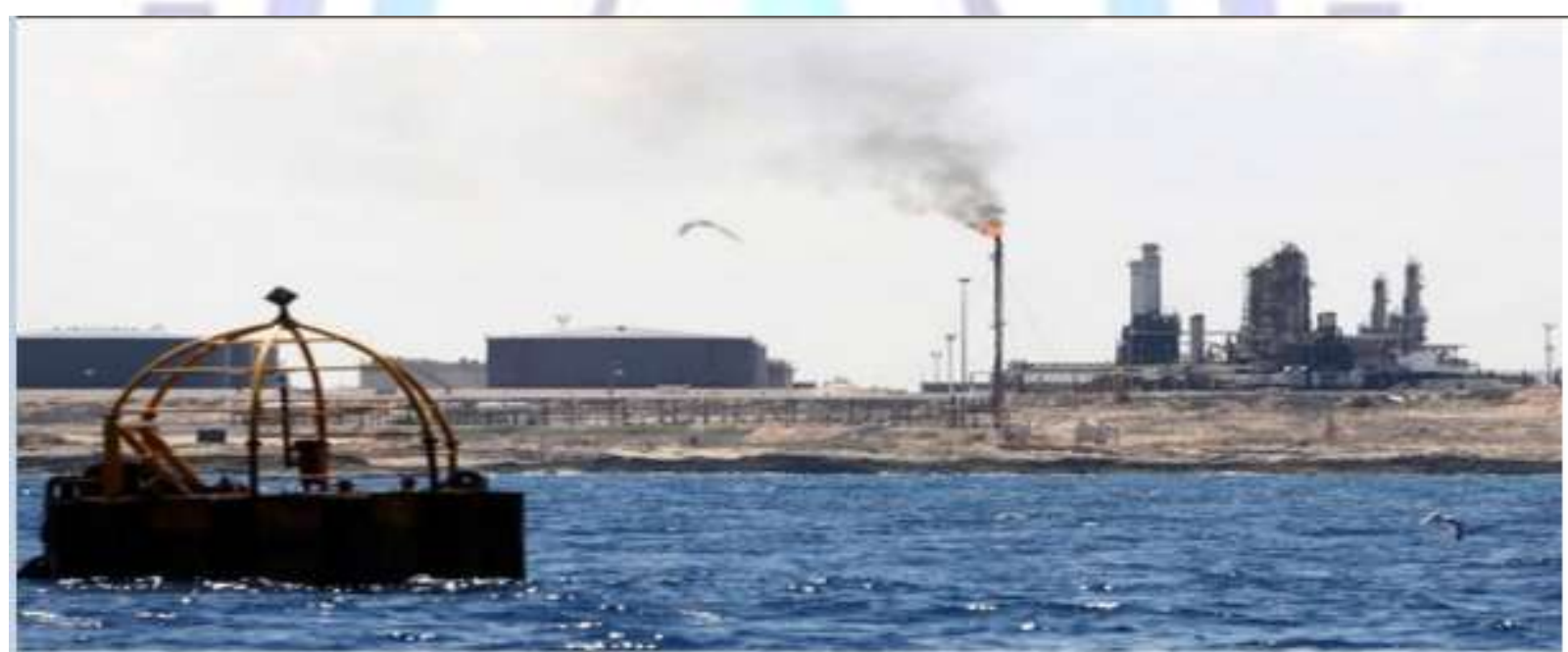

Figure 4. Another Gas Flaring Site at Residential Area in Eastern Libya Region

It has been argued that economic deprivation, unemployment, alienation, exclusion of the local elites and lack of sustainable development in the Eastern Libya region are the drivers of violent conflicts that have beleaguered the region for more than four decades. My unremitting focus here is not only to evaluate the oil violent in the Eastern Libya but also to proffer plausible and achievable short-term solutions to the problem under discussion so that the aggrieved Eastern Libya indigenes will stop resorting to violence and sabotage as a way of registering their grievances against the oil companies and the Libyan government. The section conclude that violent- conflicts in the Eastern Libya region can be avoided if the State pay sincere attention to the deep yearning among the people to be respected, recognised and acknowledged not only for their ownership of the resources but for bearing the brunt of its exploitation. It is our believe that if this happens, then the local people will rekindle hopes in the government, otherwise efforts to provide long-term solution will continue to be a sheer waste of resources and heightening of conflicts.

\section{Causes of Eastern Libya Oil Conflicts}

The oil companies were selective and racial when it comes to monetary settlement and development purposes. These gave rise to lack of consensus on how to resolve sensitive issues like resource control, developments projects, and leadership tussles among different groups. The hierarchy of conflicts in the Eastern Libya present a good insight on the nature of each conflict. The conflicts are not the same but one has a linkage to the other. For instance without understanding and resolving the various land disputes, it will almost be impossible to address the chieftaincy disputes. This is because it is only when the issue of who owns the land is settled that that of who governs it will make sense. The 
same applies to the issue of leadership of Community Development Association (CDA). Therefore, the question to be addressed are what are those grievances that caused incessant violent conflicts and why efforts made to solved have failed to achieve desired results. I think it is essential to address these grievances so as to have a grasp of the problems and then proffer reasonable solutions that will stop people from resorting to violent and any act that will cause more harm than good. However, we remind that this work this work is not going to mention all the problems or set out to solve all Libyan's problems. That could be done in some other research of different scope and time frame. Our primary interest here is to look are those critical problems that has been responsible for the violent conflicts in the Eastern Libya area. Thus some of these grievances are as follows:

- Social structure imbalances/undemocratic system

- Failure to develop the region/social injustice

- Mis-government/bad leadership towards the region/poor resource inflow

- Corruption /Empty promises of government /oil companies

- Majority ethnic domination/Minority question/ marginalisation

- Faulty Constitution/implementation crisis

- Unemployment

- Lack of an effective youth programme

- Environmental problems

There is no overstating the fact that the country's social structure is in a comatose and at the brink of total collapse and disintegration. The expectations of Libyan at the dawn of political independence were that indigenous government will deliver the country from the shackles of oppression and eliminate colonial legacies. The system of governance and political positions has been dominated and controlled by a particular ethnic region that contributes little or nothing to the economic development of the country. Where's the area that generates the wealth of the nation remains economically deprived, politically marginalised and environmentally underdeveloped, the area that contributes nothing little or nothing to the economy receives more revenue allocation.

\section{Emancipation of the Eastern Libya}

The emergence of the movement for the Emancipation of the Eastern Libya (EEL) introduced a more devastating level of violent conflict in the oil crisis. Among other militia groups, EEL has proved to be more organised, better equipped, and more determined. The group emerged to continue the struggle where Libyan army and other militias groups stopped. The groups have not deviated from the ideological struggle of self-determination and economic empowerment of the Eastern Libya people. The resolve of the group to the struggle to logical conclusion through violence means have many to criticise them. They have been discredited as a terrorist group by the government and oil companies. Some think that this criticism is unreasonable and inappropriate especially on the side of the government. It is argued that people that categorized EEL as terrorist organisation do so to discredit the group and mostly to win international support particularly to give credence to the global war against terrorism or what we call in local parlance as "giving a dog a bad to hang it". Although the activities of EEL may have caused political instability and economic loss, the fact remains that the corrupt leaders and other business capitalists benefits from the crisis and have provided arms and ammunition to the group at one point or the others.

The global oil and energy crisis caused by EEL and other militants group would have been avoided if the government and the oil companies had resorted to dialogue or mediation processes than using military might to subdue the anti-oil movements. Therefore, People should understand that whatever pushed the Eastern Libya youth to challenge and mobilise against the oil companies did not start today. It is nothing but years of economic injustice, environmental damages, and long period of political neglect suffered during colonial rule and post-independence regime. The youth involvement in the conflict is the fault of the Libyan government and not necessarily the fault of the youth. The sharing of political positions since post-revolution on the Gaddafi regime which had remained the prerogative of the political elites and community leaders which in no small way has excluded and alienated the oil producing states in Libya. The whole government affairs have remained with the same corrupt and dishonest individuals who have used their positions to influence government policies to the advantage of their families and cronies.

The only problem in this fight is that EEL and other militant groups have also "crossed the red line". They are termed terrorist group because they kidnap, and take oil workers hostage for ransom. They attack innocent citizens who have no connection with oil companies or with the State. This approach is not the philosophy of freedom fighters in the strict sense of it. However, in all sense of decency, the sectarian attacks on oil facilities, kidnapping of oil workers hostage-taking and all forms of malicious destruction is completely not the best option rather it will escalate more violence and rather counterproductive. This situation has caused socio economic and political instability and insecurity problems in the country (See Figure 5 \& 6). 


\section{ISSN 2278-5612}

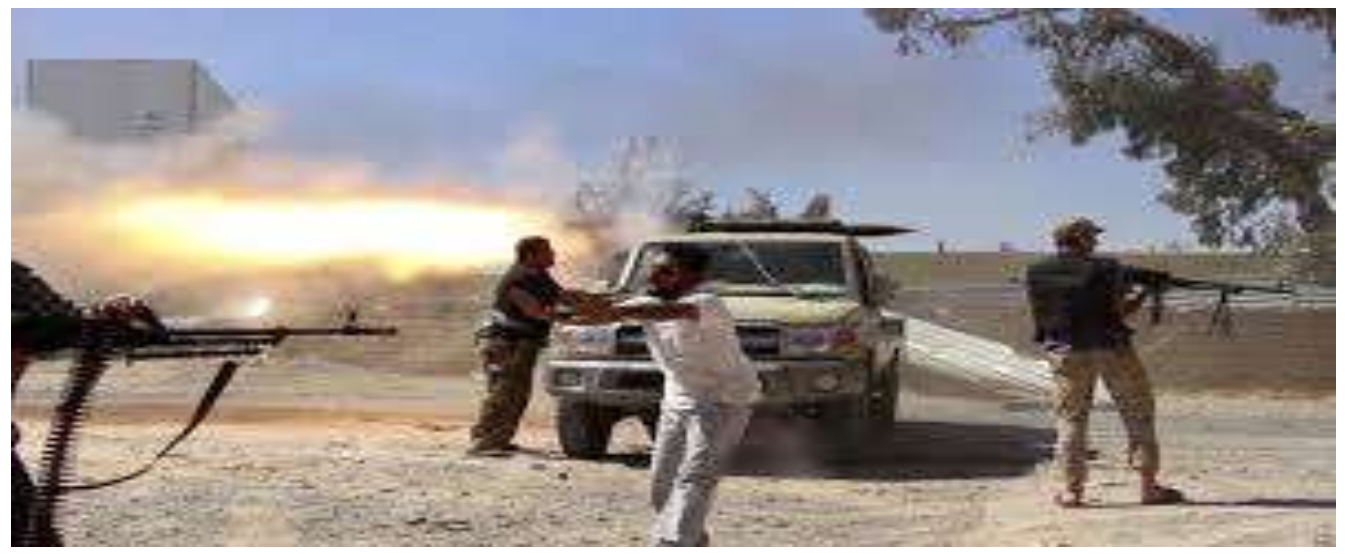

Figure 5: Rival Militias Fight for Eastern Libya's Group

Islamic State (IS) militants are said to have kidnapped nine foreign oil workers in a raid in Libya, when they reportedly beheaded eight guards. Four Filipinos, an Austrian, a Bangladeshi, a Czech and a Ghanaian were taken with an unidentified ninth foreigner, Austrian officials say. The foreign ministry in Vienna said IS had attacked the al-Ghani oil field. The foreigners were working for oilfield management company Value Added Oilfield Services (VAOS) at the field. VAOS said it did not know which militants had carried out the attack or where the oil workers had been taken (BBC News, 2015).

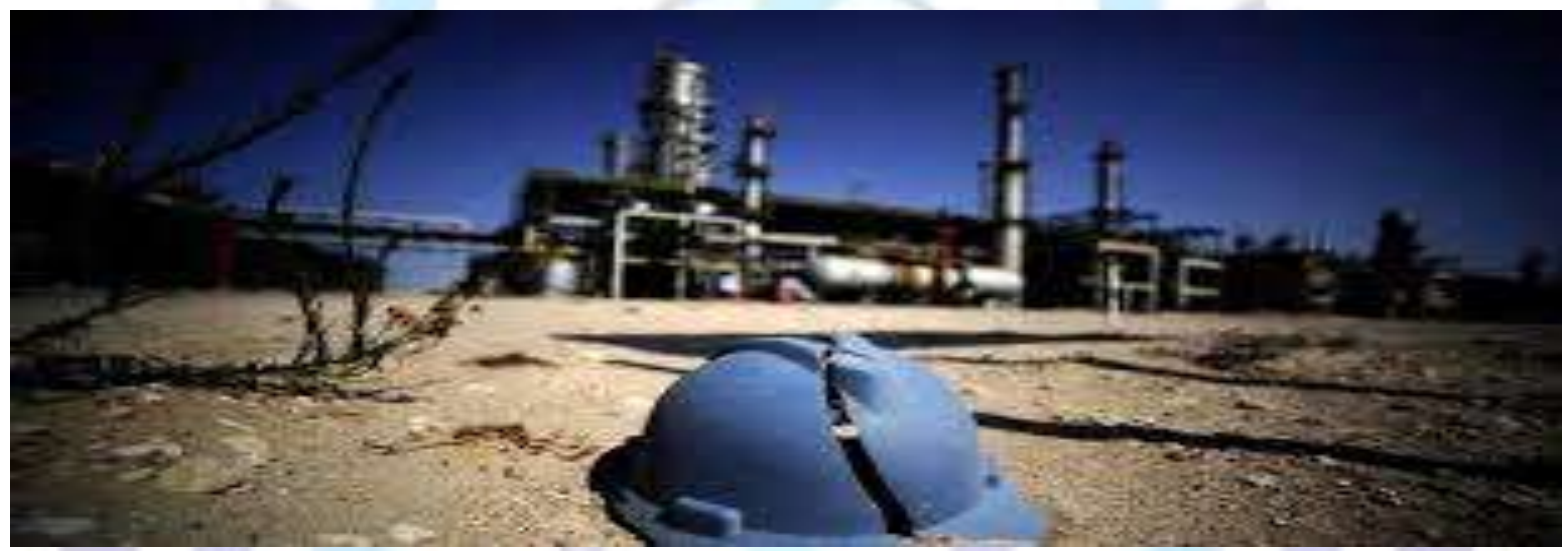

Figure 6: Kidnapped Oil Workers Being Ferried to the Militant's Base in Eastern Libya

\subsection{John Rawls Theory of Justice}

The whole idea of using Rawls is that it gives us the room to come up with proposals that will help us solve problems that has to do with distributive justice, social imbalances and instability in society. For instance, his method produces exactly what we will assist us to generate specific principles that will provide short-term solutions to the Eastern Libya oil crisis. In order words, Rawlsian method produces proposals that are suitable solutions to the problems of justice and social cooperation in society. Thus, the proposals produced by the Rawlsian method are not something people can reasonably reject and if people are committed to advance their own welfare they will reasonable agree to those proposals because the proposals provide alternative ways of solving their problems.

We believe that his theory of justice and his method of justice will help to cash out Libya's social structure problems, political instability and economic predicaments. The Rawls theory has generated both a lot of support and a lot of criticism, this chapter will not engage in either criticism or defence of Rawls. In this study, we assume that Rawls method is at least a plausible way to arriving at principles that satisfy the requirements of distributive justice and believed that his method can be usefully applied to the Eastern Libya oil crisis. Our primary focus is to use the Rawlsian method to remove all obstacles which have prevented the country from establishing political justice, economic progress, social welfare, cultural relationships, and religious tolerance and then construct a set of principles the affected parties cannot reasonably reject.

Rawls argued that it is not always the case that people's actual agreement means the agreement is unfair because there are all sorts of reasons why people might agree to what are patently unjust and unfair. In other words, people are not generally trying to arrive at a bargain that is fair and just, but a bargain that is as lopsided as possible in favour of their own interests. Furthermore, John Rawls' method is not based on utilitarian beliefs and does not rely heavily on arguments from tradition. His method is based on the OP $(\mathrm{OP})$ behind the veil of ignorance. He refers the OP as favoured philosophical interpretation of the initial situation (Rawls, 1971).Rawls intends to show that our intuition about the rules that guide the choice of principles do agree with the set-up of the initial situation. In this situation, Rawls stated that his principles of justice are the ones that the participants in the OP would choose at the end of the day. The participants would choose Rawls' principle because it has the ability to provide principles of justice that reasonable people cannot reject. Overall, the Rawlsian method is an attempt by rational persons in the OP behind the veil of ignorance to choose or reject in a rational 
and plausible process, the principle or rules that should govern the actual world. Rawls therefore believes that he has set up an inherently fair procedure that will lead to just solution to social and economic inequalities in society. Because of the fairness of the procedure which Rawls described in his method, principles, or rules that would be chosen by means of this procedure would be fair and just.

In effect, the Rawlsian method, sort out through the idea of the OP and behind the veil of ignorance is an effort guided by a number of moral, political, and social intuitions that concern the welfare of mankind generally and the disapproval of arbitrariness, inequality and other social ills (Rawls,1999). But we must note that our argument in this work is not set out to defend the Rawls rather we are going to borrow the Rawlsian method to come up with principles that free equal and rational persons would agree given their desires and aspirations. The Rawlsian solution can only work for people who are reasonable and people who are looking for a just solution but if people are looking for personal power, the only solution for those people is violence.

\subsection{A Defence of Rawlsian Method in the Search for a Theory of Short-term Justice}

One of the fundamental issues we must understand here is that the Rawlsian solution can only work for people who are reasonable and people who are looking for a just solution. But if people are looking for personal power, the only solution to deal with this kind of people is violence. So the Rawlsian solution is there to convince reasonable people to behave themselves. Our primary interest here is to extrapolate those principles of justice emphasised in Rawls theory of justice that hold the key to the enthronement of a regime of social rights and redistribution of economic benefits to everyone in society such that will have the capacity to see that no abandoned and neglected member by the State or no member left in disadvantaged position. These challenges informed our justification for choosing Rawls theory of justice among other theories of justice. This is because many people in the country today are poor and lack basic amenities of life (Rawls, 1971: 269).

The basic institutions as constituted in Libya at present have no commitment to the view of Rawls first principle of justice, that each individual has an inviolability founded on justice that should not be abused and violated not even for the purpose of achieving the wellbeing of the entire population except in cases of punishment for crimes committed against the State. But this is not. So Rawls emphases on the relationship between well-ordered society and the public conception of justice is what Libya need to get back on track in order to win the people's social union and loyalty. This will create a sense of justice that generates stronger social stability to the extent that is more likely to override disruptive inclinations, hatred, greedy that has bedevilled the Libyan polity.

To achieve these noble conditions, we need a principle of justice that provides social contract theory that will properly cash out economic and political matters in a more rational and fair process. Therefore, this is why Rawls' theory of justice is relevant and has serious positive implications for development in Libya. These ideals as extrapolated from Rawls's method of justice give us the justification for choosing this method. Moreover, it is one of the plausible means that we can employ to provide those basic principles that will help us solve our problems in the short-term course. The OP is another relevant process that has serious implications for development, peace, justice and equality in the social structure of Libya. In the first instance it reminds us that there is urgent need to enter a proper social contract that will be fair to all the parties giving different voices and different conflicting demands in Libya today.

In the real word, why would one group decide who should get oil allocation and how oil wealth should be distributed when all the groups have equally right to the natural resources? By allowing one group the right of veto, the people in the OP will end up escalating the problem and such would exude unnecessary pressure and influences. Therefore, people in the OP will not accept principles that will disfavour some and favour others but a principle that benefit everyone (Rawls, 2001). Another danger is that the group that has veto could use it to disadvantaged others or to hold everyone up. This position will delay things and the system will remain backward. To solve this problem, the parties in the OP behind the veil of ignorance would not agree to grant veto to anyone because if they do, things may get worse. As such, they would agree to principles that will be fair to them and everyone in the society.

The principle of no veto work in such a way that everybody is allowed equal opportunity and no group is allowed to have more opportunity than others. This free and equal opportunity reflects in the revenue sharing formula and allocation of resources. But if we allowed one group veto or if everyone is allowed veto, agreement would be delayed and people will end up not getting things done (Rawls, 1973). Therefore, the absence of veto will prevent the intransigent process of reaching an agreement. It has the capacity to make policies and decisions to be reached smoothly and peacefully. It is therefore argued that the absence of veto is significant in solving the political and economic problems Libya is experiencing at present. It will discourage undemocratic decisions and make opportunities open to everyone. The manoeuvrings and politicisation of issues by government and by those that have links by oil companies will be reduced if nobody is allowed veto. The removal of veto in the decision-making process will make people come to a compromise or an agreement that will enhance general good. It will make everyone participate in the affairs of the State unlike when one group exercises power of veto and hold others up.

Another consideration is that the abundant natural resources needs to be tapped and explored and people needs to agree for it to be tapped. But if people continue to disrupt oil operations such actions will amount to economic loss and will not do any group any good. And if the oil companies were sacked or prevented from exploring oil such action will be counterproductive because there will be no money to distribute and no resources to control. This will increase the level of poverty and deprivation in the area. However, the entire community will be worst-off and nobody will benefit. This is why the people in the OP will not agree to give veto to any group. Therefore, if we adopt the principle of no veto, the decisionmaking process and policy formulation will be easy to reach and the outcome will be favourable to everyone. The problem 
of disagreement and intransigent opinion that has delayed sustainable development and democratic process will be eliminated in the short-term course, while government will continue to work out on how to make things far better for everyone.

\section{Conclusion}

Perhaps one of the disturbing and contentious issues in the Eastern Libya oil crisis, where many people and even the international community see this paltry allocation as an injustice and capable of elongating oil-related violence in Libya if the issue is not addressed now. The Eastern Libya region generates 95 per cent of the country annual revenue from oil derived from their soil. They lack basic necessities of life and at the same time undergoing serious environmental damage and underdevelopment problems. In order words, the Eastern Libya people and critics of government have suggested that a reverse to the old derivation principle is the key to the oil crisis.

Therefore, since government is reluctant to grant this request, we therefore recommend 25 per cent increase in the revenue distribution and allocation process. This will help to rekindle people's hope once again and it will give them the assurance that government is sensitive and at the same time working hard to make things better. In addition, the Libyan government should establish equitable derivative formula or in the alternative reverse to old system of derivation. Again, government should ensure that the distribution and allocation process is not reduced to unnecessary protocol or bureaucracy that could lead to more frustration and hostilities from the Eastern Libya.

Clearly, we are not suggesting that people should get special compensation or that people should get more than the damage they have suffered, we are saying that people have not compensated equivalent to the amount of damage they have incurred. We differ from the generalized form of compensation where everyone gets something and if this is done, the principle of justice as fairness will make no meaning at all. This practice for instance will not be fair on some people that have suffered direct burden. Some people have suffered more than others and should be given full compensation to the amount of damage or loss they have suffered. So since people cannot veto the agreement of others, they would like to have an independent body or non-governmental organisation that will ensure that those negatively affected by the oil operations are adequately compensated. To this end, people will stop holding the country up and also avoid the resort to violence.

On that note, we believe that Libya can become the giant of Africa again, if solutions and recommendations made in this study are seen as a mechanism and as guiding principles to the complex problems of Libya. It is our uttermost conviction that police formulators, decision makers, stakeholders, and the civil society will leverage on these principles and recommendations to come up with reasonable ways of solving the political, economic, social, legal and cultural problems that have plagued the country for many decades. By so doing, it is our understanding that everyone will be able to benefit both in the long-term and short-term course and the resort to violence and counter claims will be minimally reduced.

Finally, this study did not set out to solve all Libya's problems. That could be done in another research. The study made conceited contribution to knowledge by revealing the nature and scope of Libya's problems and how it all started. Although these problems were complex and intractable, we can say that greater effort was make to single out the most salient and crucial problems which we addressed in a systematic way to allow readers form an opinion about Libya. The study is full of details and equally made uses graphic photograph to communication important information. Irrespective of what have been said and the complexities and paradoxes involved, we believe that there is "light at the end of the tunnel" for Libya.

\section{Reference}

1. Agnaia, A.A. (1996). "Assessment of Management Training Needs and Selection for Training: The Case of Libyan Companies", International Journal of Manpower, 17(3), 31-51.

2. Agnaia, A.A. (1997). "Management Training and Development with its Environment: the Case of Libyan Industrial Companies", Journal of European Industrial Training, 21(2/3), 117-123.

3. Ahmed, N., \& Gao, S. (2004). "Changes, Problems and Challenges of Accounting Education in Libya", Accounting Education, 13(3), 365-390.

4. Bait-El-Mal, M, Smith, C., \& Taylor, M. (1973). "The Development of Accounting in Libya", International Journal of Accounting, Education, and Research, 8(2), 83-101.

5. Barnes, J. (2011). 'US Wary of Libya Role', The Wall Street Journal, 12 March. Barnes, J., \& Levinson, C. (2011) 'US Drones Hit Targets in Libya', The Wall Street Journal, 25 April.

6. BBC News (2015) "Libya violence: Foreign oil workers 'kidnapped'", 9 March [online]. Available from: http://www.bbc.com/news/world-africa-31802393[Accessed 10 March 2015].

7. International Monetary Fund (2013). IMF Country Report No. 13/151-Libya: Selected Issues, May 2013.

8. International Monetary Fund (2014). African Development Bank-Libya: A Country Re-engagement Note 2014-2016, April 2014.

9. KPMG (2013). "Libya Country Profile", [online]. Available from: http://www.kpmg.com [Accessed 29 February 2015]. 


\section{ISSN 2278-5612}

10. KPMG (2014). "Libya Q3", [online]. Available from: http://www.kpmg.com [Accessed 14 February 2015].

11. Masoud, N. (2013). "Libya's Step towards Change", Journal of World Economic Research, 2(4), 7581.

12. Masoud, N. (2014a). "Background to the Libyan Economic Reform Programme Lessons and Challenge", International Review of Social Sciences and Humanities, 6(2), 91-110.

13. Masoud, N. (2014b). "A Review of Libyan's Economy, Structural Changes and Development Patterns", Bus Eco J 4:083, 4(2), 1-10. doi: 10.4172/2151-6219.1000083.

14. NKC (2014). Libya-NKC Independent Economists", [online]. Available from: http://www.nkc.co.za [Accessed 20 February 2015].

15. Rawls, J. (1971). A Theory of Justice. Cambridge, Havard University Press.

16. Rawls, J. (1973). A Thoery of Justice. London, Oxford University Press.

17. Rawls, J. (1999). A Theory of Justice, Revised Edition. Oxford United Kingdom, Oxford University Press.

18. Rawls, J. (2001). Justice as Fairness. USA, Harvard University Press. 